\title{
HLA-Antigens in Long Standing Insulin Dependent Diabetics with Terminal Nephropathy and Retinopathy with and without Loss of Vision
}

Sir,

In their recent article, Deckert and coworkers [1] find that factors other than genetic factors in the HLA-region and basement membrane thickening are responsible for the development of proliferative retinopathy. We have come to a similar conclusion in an analysis of HLA-types in 126 out of a total of 146 insulin dependent diabetics who during the period 1970-1976 received a renal transplant in Scandinavia [2]. The antigens in the B-series demonstrating significant deviations from the control population [3] are shown in Table 1. A significantly increased frequency of HLA-B8, -Bw15 and B18, and also significant decrease of HLA-B7 and -B12 as compared

Table 1. HLA-B types in transplanted Scandinavian insulin dependent diabetics, Danish insulin-dependent diabetics and Norwegian control population

\begin{tabular}{lllll}
\hline & $\begin{array}{l}\text { Trans- } \\
\text { planted } \\
\text { Scandina- } \\
\text { vian } \\
\text { diabetics }\end{array}$ & $\begin{array}{l}\text { Copenha- } \\
\text { gen, insu- } \\
\text { lin depen- } \\
\text { dent } \\
\text { diabetics }\end{array}$ & $\begin{array}{l}\text { Norwegian } \\
\text { controls } \\
{[4]}\end{array}$ & $\begin{array}{l}\text { Significance } \\
\text { of difference } \\
\text { between } \\
\text { transplanted } \\
\text { diabetics } \\
\text { and controls }\end{array}$ \\
& $(2]$ & {$[3]$} & & \\
(n) & $(126)$ & $(109)$ & $(1628)$ & $<0.0005$ \\
\hline HLA-B8 & $44 \%$ & $42 \%$ & $25 \%$ & $<0.0005$ \\
HLA-Bw15 $35 \%$ & $35 \%$ & $20 \%$ & $<0.0005$ \\
HLA-B18 & $14 \%$ & - & $5 \%$ & $<0.01$ \\
HLA-B7 & $19 \%$ & - & $30 \%$ & $<0.005$ \\
HLA-B12 & $17 \%$ & - & $29 \%$ & \\
\hline
\end{tabular}

Table 2. HLA-B antigens and diabetic retinopathy in Scandinavian insulin-dependent diabetics who have received a renal transplant

\begin{tabular}{lll}
\hline & $\begin{array}{l}\text { Retained reading } \\
\text { vision } \\
(63)\end{array}$ & $\begin{array}{l}\text { Impaired vision or } \\
\text { blind } \\
(63)\end{array}$ \\
\hline HLA-B8 & $43 \%$ & $46 \%$ \\
HLA-Bw15 & $35 \%$ & $35 \%$ \\
HLA-B18 & $10.5 \%$ & $19 \%$ \\
HLA-B7 & $16 \%$ & $22 \%$ \\
HLA-B12 & $19 \%$ & $14 \%$ \\
\hline
\end{tabular}

None of the differences are significant $(p>0.05)$ to the general Norwegian population [3] was found. Fourteen subjects had both $-\mathrm{B} 8$ and $-\mathrm{Bw} 15$, which was not in excess of the expected. The transplanted diabetics did not differ in tissue types from the general population of Danish insulin-dependent diabetics [4], indicating that tissue types do not influence the development of renal failure.

To investigate whether severe diabetic retinopathy occurs more frequently with certain tissue types, we divided our patients into two groups, 63 who were blind or had impaired vision and 63 who had kept their ability to read at the time of transplantation (Table 2). As can be seen, there were no significant differences in the distributions of tissue types in the two groups.

In conclusion, our results, like those of Deckert and his colleagues [1], do not suggest that the development of nephropathy and/or severe retinopathy is dependent on HLA types.

Yours etc.,

Jak Jervell Bjarte Solheim

\section{References}

1. Deckert, T., Egberg, J., Frimodt-Møller, C., Sander, E., Sveijgaard, A.: Basement membrane thickness, insulin antibodies and HLA-antigens in long standing insulin dependent diabetics with and without severe retinopathy. Diabetologia 17, 91-96 (1979)

2. Joint Scandinavian Report: Renal transplantation in insulindependent diabetics. Lancet 1978 II, 915-917

3. Thorsby, E., Bratli, A., Engeset, A.: HLA-antigens in Hodgkin's disease, II. Clinico-pathological correlation analysis of 132 Norwegian patients by histocompatibility testing. In: Histocompatibility testing. pp. 587-591. Copenhagen: Munksgaard 1973

4. Nerup, J., Platz, P., Ortved Andersen, O., Cristy, M., Lyngsøe, J., Poulsen, J. E., Ryder, L. P., Staub Nielsen, L., Thomsen, M., Svejgaard, A.: HLA antigens and diabetes mellitus. Lancet 1974 II, 864-866

\section{J. Jervell}

Department of Medicine

B. Solheim.

Tissue Typing Center

Rikshospitalet

Oslo 1, Norway 